\title{
Biodiversity in some lentic habitats from southern South America \\ I. Hydrophilidae Berosini and Hydrophilini (Coleoptera, Hydrophiloidea)
}

\author{
J. S. DENTON ${ }^{1}$ and A. OLIVA ${ }^{2}$ \\ ${ }^{1} 26$ Bow Street, Alton, Hants GU34 1NY, England, UK. ${ }^{2}$ División Entomología, Museo Argentino \\ de Ciencias Naturales "Bernardino Rivadavia" Av. A. Gallardo 470, 1405 Buenos Aires, Argentina
}

\begin{abstract}
Samples of aquatic Coleoptera were taken from 9 sites in subtropicaltemperate southerm SouthAmerica. A new species and several new regional records are reported. The regional affinities of swimming and crawling Hydrophilidae in lentic habitats are discussed in the context of river basins.
\end{abstract}

Iey words: Hydrophilidae, lentic habitats, biodiversity.

Studies of aquatic insects tend to concentrate on lotic habitats, especially mountain streams, because organisms adapted to such environments are usually very sensitive to alteration of their habitat.

Lentic water bodies, however, have both academic and practical interest, as biodiversity in the major groups of aquatic Coleoptera (Dytiscidae and Hydrophilidae) is greatest in such environments. In vast areas of South America, the distinction between permanently, periodically or accidentally flooded lands may be vital to natural resource management. The pressure to drain wetlands is increasing, so there is a real need for more data about biodiversity in order to identify the most important areas for conservation. Man-made water bodies, such as rice-fields and dam lakes (an important source of electric power) should also be considered.

This paper is based on samples taken by the senior author during the austral summer of 1995 . 96. The main targets were two National Parks in areas of unusual characteristics, one, the montane Itatiaia National Park (Brazil: Rio de Janeiro state, on the Serra da Mantiqueira), and the lowland Iberá National Park (Argentina: Corrientes province, on the edge of the Iberá lowlands). Other localities were sampled as travelling allowed, but with special interest for those at or close to National Parks or Nature Reserves. We thank Dirección de Parques Nacionales, of Argentina, for permission to collects at Iberá Natural Reserve. The material from Calilegua and Itatiaia was taken outside the Parks proper.
Itatiaia NP straddles the Serra da Mantiqueira, a peculiar environment, where dry, stoney foothills give way to rainforest with a rich diversity of species, including epiphytes. Several Dryopidae were found in streams. However, in this paper we concentrate on the samples taken in a large stagnant pond some $4 \mathrm{~km}$ north of Itatiaia (in the grounds of the Hotel Repouso). It had a stony substrate with little emergent vegetation, and contained large numbers of fish.

Several species of Berosini are known only from Rio de Janeiro, which is close to Itatiaia NP. This made it all the more important as a collecting site.

The interest of the Iberá system lies in its unique geological formation. The province of Corrientes has roughly the shape of a trapeze, with the broadest side made up by the northern limit (marked by the river Paraná, which here flows nearly in an East-West direction). According to Neiff (1981), the province appears as a great plain with the highest ground (about $200 \mathrm{~m}$ above sea level) in the NE and the lower (about $40 \mathrm{~m}$ a. s. 1.) to the SW. The central depression of the Ibera covers about 1,200,000 ha. Low sandy bars alternate with vast areas, flooded either permanently or periodically. The plain was covered by a Triassic lava flow and afterwards suffered marine ingression. During the Tertiary, the area of Mercedes (which is close to the Ibera National Park) and the eastern part of the province were raised, while the western sector subsided. Finally, during the Quaternary period there was a raising of the whole land between the rivers Paraná and Uruguay (called 
"Mesopotamia" in Argentina, and made up by the provinces of Misiones, Corrientes and Entre Ríos), and the river Parana settled into the new bed, which is a geological fault.

Neiff (1981) describes six basic types of lentic water bodies in NE Argentina:

a) Isolated ponds; primary productivity high; accumulation of dead organic matter low. Substrate sandy. Relatively young; water comes partly from superficial draining, partly from phreatic circulation. On the north-western sector of the province.

b) Isolated ponds; low primary productivity. On fine-grained soil with a high calcium and sulphate contents. On the Chaco plain.

c) Isolated ponds; primary productivity high, by vascular plants; acumulation of dead organic matter high. Substrate sandy or clayey-sandy; a superficial horizon of varying thickness $(0.1-2.0$ $\mathrm{mm}$ ) of ooze of vegetal origin. Water transparent (Secchi disk 70-100\% total depth), ambercoloured because of organic content, of low saline content, rarely with thermic stratification save in densely vegetated sectors near the shore. Very rich in insects. Free water made up only $20 \%$ around 1980, and it may have decreased due to the advance of "esteros". However, the combination of lentic waters and sandy substrates is very unusual outside this system; this sort of water body is the most interesting to assess biodiversity.

d) Pools connected to streams and rivers; primary productivity high, by vascular plants; acumulation of organic matter low. Mainly around the Paraná-Paraguay system.

e) "Esteros": permanently flooded, densely vegetated areas; substrate originated by the remains of dead plants, with numerous pores bearing water of phreatic (in less quantity pluvial) origin, acid and of a higher saline content than water of other ponds.

f) "Bañados": seasonally flooded areas, including some used for rice growing and others used as pastures in dry season. Flooding may be due to river spates or to rain.

Among several families of aquatic beetles sampled, the Hydrophilidae have been chosen for a first paper, and within this family, the two main aquatic tribes, namely Berosini and Hydrophilini (sensu Hansen, 1991).

\section{MATERIAL AND METHODS}

The insects were netted, killed and drymounted in the usual manner, and the characteristics of the environment noted. The material is kept in the collection of the senior author, with the exception of four specimens that proved a new species (see Oliva, 1998), and of two more that represented new geographical records, and which are kept at the Museo Argentino de Ciencias Naturales. These are marked with asterisks.

\section{RESULTS}

1. Brazil: State of Rio de Janeiro: Itatiaia. Large stagnant pond, rocky substrate, a little emergent vegetation; Gyrinids on surface; many fish observed. 5/11/1995.

Berosus margaritinus Oliva, 1998*

Hemiosus moreirai Orchymont, 1921 ${ }^{\text {* }}$

Derallus anicatus Orchymont, 1940

Tropisternus ovalis Castelnau, 1840

2. Argentina: Province of Misiones: Puerto Iguazú. 12/11/1995. Shaded stagnant forest pool. Tropisternus apicipalpis Chevrolat, 1834 Helobata cossyphoides (Bruch, 1915)

3. Argentina: Province of Misiones (Dpto. Candelaria): Mártires. Road bridge, about $19 \mathrm{~km}$ NE of Santa Ana. Shallow, weedy marshy pool in a grazed field, with many emergent tussocks; remarkably rich in insects. 15-16/11/1995.

Berosus minimus Knisch, 1921

Berosus reticulatus Knisch, 1921

Derallus paranensis Oliva, 1981

Tropisternus setiger (Germar, 1824)

4. Argentina: Province of Corrientes: Iberá. Camp site near Laguna Iberá; shallow seasonal pools in flooded fields ("bañado" sensu Neiff); also a deep, permanent lake with weeds ("estero" sensu Neiff). 11/1995.

\section{Berosus minimus}

Berosus corumbanus Knisch, 1921*

Berosus patruelis Berg, 1887

Berosus pedregalensis Jensen-Haarup, 1910

Berosus reticulatus

Berosus decolor Knisch, 1924

Derallus angustus Sharp, 1882

Tropisternus lateralis limbatus (Brullé, 1837)

Tropisternus collaris (F., 1775)

Enochrus vulgaris (Steinheil, 1869)

5. Argentina: Province of Buenos Aires: San Clemente del Tuyú. Weed-choked ponds fringed with tall emergent vegetation. 25/11/1995.

Berosus festivus Berg, 1887

Berosus coetacanthus Oliva, 1989

Berosus pedregalensis

Tropisternus setiger

Tropisternus ignoratus Knisch 
6. Argentina: Province of Salta: J. V. González. Enochrus vulgaris

7. Argentina: Province of Jujuy: Calilegua. Bare pools with silty substrate among shingle bars of river, undoubtedly inundated during spates. 1/ 1996.

Berosus auriceps Boheman, 1859

Berosus reticulatus Knisch, 1921

Hemiosus bruchi Knisch, 1924

Tropisternus flavescens, Orchymont, 1922

Enochrus circumcinctus (Bruch, 1915)

8. Bolivia: Department of Santa Cruz: (Prov. Sara): Buena Vista. Weedy marsh dykes (near río Surutu) 27/1/1996.

Berosus holdhausi Knisch, 1921

Berosus truncatipennis Castelnau, 1840

Tropisternus collaris

9. Bolivia: Department of Santa Cruz: Sajta. Stagnant forest pool, open and free of weeds. $20 /$ $1 / 1996$.

Berosus holdhausi

Berosus auriceps

Enochrus obsoletus (Bruch, 1915)

Tropisternus laevis (Sturm, 1826)

\section{DISCUSSION}

1. Itatiaia: although not large, the sample provided some important records, including a new species of Berosus, and the first specimen of Hemiosus moreirai known outside the typematerial from Rio de Janeiro. Both species are remarkable, with a smooth dorsal surface compared to related species. It may be added that Hemiosus dimorphus Orchymont, 1940, known only from Rio de Janeiro (type-locality) and Santa Catharina, is also remarkable by a smooth dorsal surface. Old records labelled "Rio de Janeiro" may well refer to the hinterland of the province rather than the city and its immediate environs.

The new species is unique, with a subglobular shape recalling that of Derallus. Conversely, Derallus anicatus, which was found in this sample, is a large species (c. $4 \mathrm{~mm}$ ) with smooth elytral disk. The size and sculpture might be adaptative to avoid predation by fishes. The smaller species of Derallus $(2-2.5 \mathrm{~mm})$ would presumably be easily snapped up.

The presence of Tropisternus ovalis is remarkable, as this species is usually associated with floating plants, especially Salvinia spp.

2. Iguazu: the single species recorded is widespread in the Northeast of Argentina.
3. Mártires: interesting only as intermediate locality record for the three species. Berosus minimus is a widespread species, but this appears to be the first record of it for Misiones province. $B$. reticulatus in Misiones came from the eastern tip of the province (Oliva, 1989). Derallus paranensis is known from the middle and lower course of the river Paraná, from the NW of Argentina, SE of Bolivia and northern half of Paraguay (Oliva, 1981).

4. Iberá: $B$. corumbanus is a new record for Argentina (Oliva, 1997). The fact that it was found with such species as $B$. pedregalensis, $B$. patruelis and $B$. reticulatus shows this species to be allied with young water bodies rich in organic matter. The species obtained at the Iberá station are interesting rather as intermediate locality records than because of any peculiarity of their habitat preference. This is to be expected from seasonal ponds. As to Laguna Iberá itself, Tropisternus collaris was extremely abundant among the vegetated fringes. Many species were also abundant in ponds connected to river systems. In fact, the sort of pools sampled in this expedition were perhaps not the most representative of this extensive and unusual wetland system.

Certain species, notably members of the genus Hemiosus, are associated with sandy substrates. One species is widespread in the province of Entre Ríos, south of Corrientes; another two have been found at Misiones, one of which appears also in Uruguay (Oliva, 1994). No information is available for Corrientes, but it is likely that some species occur in ponds with sandy substrate, which do occur in the province. It would be of interest to know whether the psammophilous fauna of Corrientes resembles that of Misiones at the North east or that of Entre Ríos at the South. More extensive sampling is needed.

5. San Clemente del Tuyú: a bathing resort on the Atlantic coast, near the mouth of the Río de la Plata. A large network of marsh dykes and seasonally flooded ground occurs in the low-lying hinterland. The sample shows high diversity without having a special fauna. Both Berosus pedregalensis and Tropisternus setiger are quite common pioneer species. Berosus festivus and $B$. coelacanthus look very much alike, and may be distinguished by small morphological characters of the ventral structures and of the male genitalia. Intriguingly, when both species occur together, each one usually shows a different degree of sclerotizing. San Clemente del Tuyú is 
just south of the $36^{\circ} \mathrm{S}$ parallel, which is the known southern limit for B. coelacanthus. Berg's species extends further south, at least to General Roca in the province of Río Negro, at $39^{\circ} \mathrm{S}$.

6. J. V. González: a locality of no special interest, save in that it is placed just within the Chaco plain. Enochrus vulgaris is a very common, pioneering species.

7. Calilegua: the environment is characteristic of the NW and centre of Argentina, and both Berosus auriceps and Hemiosus bruchi are commonly found there (Oliva, pers. obs.). $B$. reticulatus is a pioneering species confined in Argentina to the northern half of the country (Oliva, 1989). Tropisternus flavescens is a widespread, rather pioneering species common in the Andean highlands, although there are some records from low altitudes.

8. Buena Vista: the vast flat area of Santa Cruz is continuous with the Chaco-Pampean plain. The water-beetle fauna resembles that of Corumba and the Mato Grosso lowlands, rather than that of the Andes.

9. Sajta: a forest pool is always interesting. Berosus holdhausi is rarely abundant, but ranges from Corumbá in Brazil: Mato Grosso (from where it was first described) to Argentina: $\mathrm{La}$ Rioja: Iliar, c. 30'30'S (Oliva, 1989). It had been recorded from El Cidral (Santa Cruz. department). Most of the previous records are from tree-less areas. At Sajta the beetles were fớund in flooded wheel-ruts in a small forest clearing. It is likely that this is a pioneering species of new pools devoid of fish, where its poor swimming ability (due to coarse dorsal sculpture and sturdy shape; Oliva, 1989) is less important.

\section{CONCLUSION}

The study of lentic habitats throws some light on insect distribution as related to river basins. Thus, species described from Corumbá appear in lbera because of the connection through the river Paraguay.
Proper studies of Biodiversity in lentic habitats, especially areas threatened by draining schemes and/or global climate changes, require methodically prepared expeditions, and an appropiate level of funding.

\section{ACKNOWLEDGEMENTS}

We thank Dr Axel O. Bachmann (Museo argentino de Ciencias naturales) for determination of the species of Tropisternus, and Dr. Liliana Fernăndez (Facultad de Ciencias naturales y Museo, La Plata) for determination of the Acidocerina.

\section{BIBLIOGRAPHY}

Hansen, M. 1991. The Hydrophiloid Beetles. Phylogeny, Clasification and a Revision of the genera (Coleoptera, Hydrophiloidea), Biolog. Skrifter 40: 1-367

Neiff, J. J. 1981. Panorama de los cuerpos de agua del nordeste argentino. Symposia VI Jornadas arg. Zool. (La Plata, 18-23 Oct 1981). III. Ecologia: 115151

Oliva, A. 1981. El género Derallus Sharp en la Argentina (Coleoptera, Hydrophilidae), Revta Soc. ent. arg. 40(1-4): 285-296

- 1989. El género Berosus (Coleoptera: Hydrophilidael en América del Sur. Revta Mus. arg. Cs nat. (Ent.), 6(4): 57-235. Buenos Aires.

- 1994. A revision of the genus Hemiosus Sharp, 1882 in South America (Coleoptera: Hydrophilidae.

Bull. Annls Soc, r. belge Ent., 130 (7-9): 267-303

- 1997. Berosus corumbanus Knisch, 1921 (Coleoptera, Hydrophilidae) nueva cita para la Argentina. Physis (Buenos Aires) B: 18.

- 1998. A new species of Berosus Leach from Southeastern Brazil (Coleoptera: Hydrophilidae), with some comments on the possible evolutionary pressure of Hydrodynamics factors. Bull. Annls Soc. r. belge Ent.131 (3): 239-246.

Recibido: 15-XI-1997 Aceptado: 2-X-1998 